\title{
“Can Anybody Fly This Thing?” Appropriations of History in Reenactments of Operation Market Garden
}

\author{
Wolfgang Hochbruck
}

A modern military transport plane flies over a field, parachutists jumping out of its rear hatch. It is followed by a World War II vintage twin-engine bomber. Above the noise of the engines, the guitar of Jonny Buckland is heard, and then the voice of Coldplay lead vocalist Chris Martin with the first line of "High Speed:" "Can anybody fly this thing?" (Hemmen 20o9). The video by one Paul Hemmen is one of about forty YouTube amateur videos that were sampled for this study. All of them cover 21 st century commemorative reenactments of the 1944 World War II airborne Operation Market Garden, ${ }^{1}$ and all of them make use of para-filmic techniques, and a musical score. Fittingly enough, the album on which the Coldplay song appeared was named Parachutes (2000).

It is the tentative link between commemoration, reenactment, filmic, and musical culture that the present essay is interested in. "History's affective turn," as Vanessa Agnew has called it (Agnew 2007), has brought individual narrative, emotional experience, and affective responses to the forefront of scholarly historical discourses. As a side effect of this turn, scholars have become more aware of the realm of citizen scholars, aficionados, and mere hobbyists, who take history into their own hands, and re-stage historic events as reenactments, and then upload them to YouTube. However, as I will try to show, whereas there is a moment of reappropriation of both theatre and history in these activities (cf. Hochbruck 2012), few if any of the reappropriations - the shows as well as their representations in videos on the web-take place outside the well-demarcated hegemonial frame.

The last decade has seen a marked increase of interest in reenactments as a social and historical phenomenon, and some excellent scholarship in the field

1 I was invited to observe the 7oth anniversary commemorative reenactment of the crossing of the Waal River by us forces which originally took place on Sept. 2oth, 1944. My experiences as an American Civil War scholar, and reenactor, and a previous study on reenactments of the Civil War battle of Gettysburg (July 1-3, 1863; Hochbruck 2016) seemed to indicate that the Waal / Market Garden events were indicative of a category not listed in my own typology of Living History presentations (Hochbruck 2013).

(C) WOLFGANG HOCHBRUCK, 2018 | DOI 10.1163/9789004292017_007

This is an open access chapter distributed under the terms of the prevailing CC-BY-NC License at the time of publication. 
(Agnew 2004, McCalman/Pickering 2010, Schlehe et al. 2010). However, there are less than a handful of publications on World War II reenactments that might be called useful according to scholarly standards, and only one major study: Jenny Thompson's War Games (Thompson 2004) is an ethnographic treatise of the men and (few) women participating in these recreations of war scenarios on a variety of mostly private sites in the United States (Berens 2008).

The material analysed for this essay, as well as the method and the theory behind it, follow a different approach. For one, the videos and short films of the Market Garden reenactments for the most part cover commemorative events that take place on an annual basis in the vicinity of the original dates, and on or near the original sites. The September 1944 Operation Market Garden events involved British, American, Polish, and Canadian airborne and ground forces, Dutch civilians, and German Wehrmacht and Waffen-ss units, fighting and suffering along a corridor from Eindhoven to the greater Arnhem area. Commemorative events celebrating what was a failed attempt at liberating the Netherlands have proliferated and expanded over the last fifty years. They now include memorial services and parades as well as parachute jumps, and crossings of the river Waal. Operation Market Garden has also been turned into two major films, the star-studded Richard Attenborough-directed Joseph Levine production A Bridge Too Far (1976), and Theirs is the Glory (Hurst 1946; see the essay by Laszló Munteán in this volume) from the immediate post-war period, which used many original participants in prominent and supporting roles. The participation of reenactment groups in the current commemorative events, parades, and pageants on the historic sites near Arnhem and Nijmegen is the standard, and individuals and groups travel long distances in order to attend.

The bandwidth of events, and the ensuing multiplicity of overlapping perspectives and performative agendas, ranges typologically from the symbolic via pageantric representations to live-action role play, and they involve original participants and their descendants, other war veterans, contemporary members of units that were involved in the historical events, present-day reenactors, the local population, and of course numerous tourists from a variety of countries.

The interfacing of these typologically different formations means that the methodological basis needs to be reassessed. The term "reenactment" is used here for a variety of theatrical formats, all of which aim at a re-staging of events, based on various concepts (and consequently performances) of historical accuracy. It is, for instance, used for reconstructions of stage productions (cf. Fischer-Lichte 2012, 38-47), and in this context the term is used most appropriately in so far as reenactment assigns, semantically, to the original event the role of an enactment. In the historical field, however, enactments are most likely to take the form of rituals and ceremonies, diplomatic encounters 
and state actions, in so far as they follow elaborate scripts. Many of them are reenacted as regular theatrical events to reaffirm local, regional, or national identities - and of course as tourist attractions.

Reenactments in the more limited sense as staged celebrations of past military occurrences are likewise re-constructions. The link to the enactment in this case is more tentative, though justifiable in so far as the staged structure of reenactments reinforces the public sense of the eventual outcome. As a theatrical practice, they are traceable to ancient Rome, and like with other forms of public theatre there is both a ritual and a political side to their performance. As part of the political theatre, they have been used in hegemonial processes as integral parts of the performativity of power (Hochbruck 2013). Within this system, reenactments need only to be scripted to a limited degree since they tend to follow certain sets of conventions accepted by the majority of participants. Reenactments reproduce an agreed-on set of historiographic accounts, rather than the past.

However, while this holds true for most of reenactment history, including the current practice, postmodern reenactment culture is at least theoretically, and strategically, also a form of theatrical reappropriation of history, and therefore at least potentially a theatrical format that can be used for cultural and social empowerment (Hochbruck 2012). Reenactments are also simply a legitimate form of theatrical entertainment, though they have not been seen, leave alone treated, as a part of the field of Theatre \& Drama Studies for most of their existence. Instead, much of the discourse on reenactments has focused on issues of authenticity. However, the perception of authenticity changes as the historical events — and their original participants — gradually recede into history. The mode and method of authentification is transferred from original participant in military events and objects to accurately reproduced equipment and precise evolutions. The functions of reenactments can therefore be summarized as

- (socio-)political / historical

- mnemotechnical / ceremonial

- aesthetic/ entertaining

For the set of Operation Market Garden reenactments, this means that there are interfacing and interacting formats. A mediaeval festival or an "Indian" camp are reenactments of "distant" pasts, places, and peoples. By comparison, the Operation Market Garden events are reenactments of proximity in so far as in terms of both time and space, nationality/-ies, and social structures, the events are located within reach. As part of a regional, and national, historical and cultural heritage, they are grounded in what Jan Assmann calls social memory (Assmann J. 1995): still embodied in memories of actual participants and their 
descendants they are still part of "communicative memory" (Connerton 1989, Assmann A. 2006, Assmann J. 2008). Now in post-authoritarian societies, memory and commemoration are increasingly pried loose from hegemonially arranged structures, and appropriated by interested groups (Langenohl 2008). This opens their structures to more democratic, bottom-up approaches and appropriations (see Hochbruck 2012), but unfortunately this is not necessarily a progressive turn. Especially commemorations, and also reenactments, of the World Wars are constantly in danger of being appropriated by reactionary and neo-nationalist forces celebrating war and nationalist values.

The feature of historic authenticity, so central to Living History Interpretation programmes in museums (Hochbruck 2013,42), is only one of a variety of aspects that might be considered in connection with reenactments. With the gradual transition from local historical events to contemporary reenactment scenarios, four steps can be identified by which the interpretatory power gradually shifts from the original participants and participants-as-historians to the next generation of their descendants, and subsequently to new generations of descendants and nondescendants whose performative practices attempt to create authentic (if usually downscaled) representations of the original events (Hochbruck 2015). The focus of the authentification method shifts in the process from veteran-centred, via descendant- and operational-movements-centred, to authentification by means of a replicated object-level and attempts at enacted proximity.

\section{Reproduction to Replication: Four Steps}
1. Staging the event as reproduction documentations photographs memorials documentaries
2. Reenactment by Veterans themselves Reunions
3. Reenactment by the Next Generation / Reenactment as Symbolic Action Descendants of the original participants and / or
the next generation of military personnel recreate
operational movements and parades, often with
veterans present as guests of honor
4. Reenactment as Scaled Replica Reenactments as attempts at object- (and operation-)centred replication

This system casts some doubt on Jean Baudrillard's widely accepted notion that the "real" disappears in media simulations and that the "definition of the 
real becomes that of which it is possible to provide an equivalent reproduction" (Baudrillard 1983, 146). The closest one might get to Baudrillard's idea of a media-generated hyperreality should, technically, be where the proximity to the filmic mode is closest. Even though comments by reenactors about their own practice have been pointing in this direction, the importance of the filmic mode and method in reenacting still appears to have been underestimated so far: As Jenny Thompson found out, many reenactors "produce and simultaneously consume their own illusions- 'watching it while acting in it.' No longer are they passive viewers in a movie theater ... they have assumed the powerful, dual roles of creator and participant in a war experience" (Thompson 2004, 170). This seems to be in line with Frederic Jameson's contention that the postmodern period saw "the transformation of reality into images, the fragmentation into a series of perpetual presents" (Jameson 1988, 28). In the case of the material researched here, the images even come with a musical score.

Whereas the statement about production and consumption of their own illusions has a ring of truth to it, Thompson (as well as several other critics of reenactment events) possibly overestimates the identification level because of the kind of events that she attended, which took place on private sites in the U.s., with the reenactors playing for themselves, and each other. Commemorative events do not aim at recreating a past-as- present for all; usually only selected objects and individuals get transferred-the historic tank, the living veterans and eyewitnesses, or (increasingly) their descendants. Also, reenactors are always actors, and in the vast majority of cases consciously (often self-consciously) so: the immersive performance in a reenactment means taking over the (often generic) role of a rank-and-file participant, but it does neither involve real timetravel nor a lasting status change. The near (i.e. filmic) "identity" of original and replicated event leading to the sensory experience of a "period rush" or "history flash" (Hochbruck 2013, 93) is only possible where the re-created past is constructed as an attempted unified whole with 'other'-worldly qualities, suggesting a touch-zone that is authenticity-based in terms of object level and qualities of reenacted space (i.e. without anachronistic structures).

For the postmodern reenactor at a commemorative event, however, this is but one of three "touch zones" in which to interact with history, true to the observation that historical learning is becoming more and more an affective, individualized, and story-based process. I would like to suggest a distinction between

1. an authenticity-based touch zone: with its filmic "identity" of original and replicated event,

2. a spatial touch zone: original event sites, original objects (cf. Hochbruck 2008), and 
3. a genealogical touch zone: including contact with original participants (primary) or their descendants (secondary).

Applying the abovementioned hypothesis about the four steps to the form in which they present themselves in chronological succession for reenactments of, for instance, the much-reenacted American Civil War battle of Gettysburg (orig. 1863, see Hochbruck 2016), and of Operation Market Garden, it might become more apparent why the most recent generation of living history presentations shows a wider bandwidth of phenomena simultaneously, and is in less danger of creating hyperrealities in the Baudrillardian sense.

Four Steps Model: Gettysburg/Operation Market Garden

\begin{tabular}{|c|c|c|c|c|c|}
\hline 1. & 1863 & $\begin{array}{l}\text { Battle of Gettysburg } \rightarrow \\
\text { National Cemetery }\end{array}$ & 1. & 1944 & $\begin{array}{l}\text { Operation Market } \\
\text { Garden }\end{array}$ \\
\hline 2. & 1890 & $\begin{array}{l}\text { National Park, } \\
\text { Veterans Reunions }\end{array}$ & $1 . \& 2$ & 1946 & Film Theirs is the Glory \\
\hline $2 . \& 3$ & 1913 & Sesquicentennial & $2 . \& 3$ & $\begin{array}{l}\text { since } \\
1970 \text { os }\end{array}$ & $\begin{array}{l}\text { Reunions \& Symbolic } \\
\text { Restaging }\end{array}$ \\
\hline 3. & 1938 & $\begin{array}{l}\text { 75th Anniversary } \\
\text { "Last Meeting of the } \\
\text { Blue and Gray" }\end{array}$ & & & s. a. \\
\hline 4. & 1963 & $\begin{array}{l}\text { Centenary } \\
\text { Reenactment }\end{array}$ & & & \\
\hline 4. & 1993 & Film "Gettysburg" & & 1976 & Film A Bridge Too Far \\
\hline 4. & $\begin{array}{l}1998 \& \\
2013\end{array}$ & $\begin{array}{l}\text { Reenactments with } \\
\text { nearly original } \\
\text { participant figures }\end{array}$ & $\begin{array}{l}2 . \& \\
3 . \& 4 .\end{array}$ & 2014 & $\begin{array}{l}\text { Symbolic reenactment \& } \\
\text { parades \& veterans \& } \\
\text { descendants of veterans }\end{array}$ \\
\hline
\end{tabular}

A closer look at the bottom bar helps to explain the difference: At 135th Gettysburg in 1998, a total of almost 15 .000 reenactors managed to recreate Pickett's Charge against the Union positions on Cemetery Hill almost on a one-toone scale. The requirements for participation that each participant had received ensured a considerable degree of homogeneity in terms of arms, equipment, and accoutrements. By comparison, the 7oth anniversary reenactment of the Waal crossing (20 Sep. 1944) by units from the 82nd Airborne Division involved a company of present-day U.S. paratroopers. No attempts at historicizing uniforms or boats were made, but several veterans of the crossing as well as some 
descendants of original participants were allowed in the boats with the soldiers of the 82nd (Nieuws uit Nijmegen 2014). ${ }^{2}$ Covering fire, historically provided by General Brian Horrocks xxx. Corps Irish Guards tanks, was present courtesy of the Dutch army: an armored personnel carrier, some machine guns and a mortar unit. And then there was a five-piece British 25-pounder battery manned by reenactors. Their opening shot was fired by a British ww2 veteran artilleryman. Neither the guns nor the old gunner had been historically present.

The simultaneous presence of veterans, their descendants, and modern soldiers, and of modern-type reenactors using replicated as well as original uniforms, accoutrements, and ordinance, appears to be a fairly recent phenomenon and so far apparently limited to First and Second World War commemorative events.

What can be observed here is that there is a simultaneity of what in the case of the Civil War were successive stages, and that there is, probably because of this constellation, a far higher degree of homogeneous "authenticity" in the Civil War reenactments. The Civil War reenactment attempts to create a documentary mode and atmosphere; the added value lies in the suggested eye-witness position of the observer. From the point of view of didactics of history, the staged interpretation of an event is presented as representative of historical truth. The filmic mode of presentation, often with voice-over narration and appropriately selected music - i.e. Civil War era marches and tunes—does not diminish this impression at least for the audience, in so far as they are used to it from movies and history channel documentaries (cf. Schlote/Voigts-Virchow 2008, 113).

By comparison, World War II scenarios like the Waal crossing have a more strongly dissociative potential. The co-presence of diverse time-periods for instance at the 7oth anniversary Waal crossing kept referring to its own historicity, and to the symbolically charged staging of the events witnessed. The audience at Nijmegen on 20 September 2014 was never allowed to forget the commemorative nature of the reduced drama before their eyesreduced to symbolic action for commemorative purposes also in so far as there was no attempt at "reality" beyond exploding some blackpowder charges on the other side of the Waal. The Volksgrenadiere-boys, and old men-defending the German positions were not reenacted. In fact they were hardly mentioned at all. ${ }^{3}$

2 One news channel video from the $65^{\text {th }}$ anniversary reenactment jumps actually shows German paratroopers taking a nap right at the start (- oo:38), but fails to mention their presence in the voiceover narration, only mentioning Dutch, British, American, and Polish participants (EDtv.nl 2009).

3 Only by Doug McCabe, one of the speakers at the semi-attached conference at Radboud University (see McCabe, 2014). 

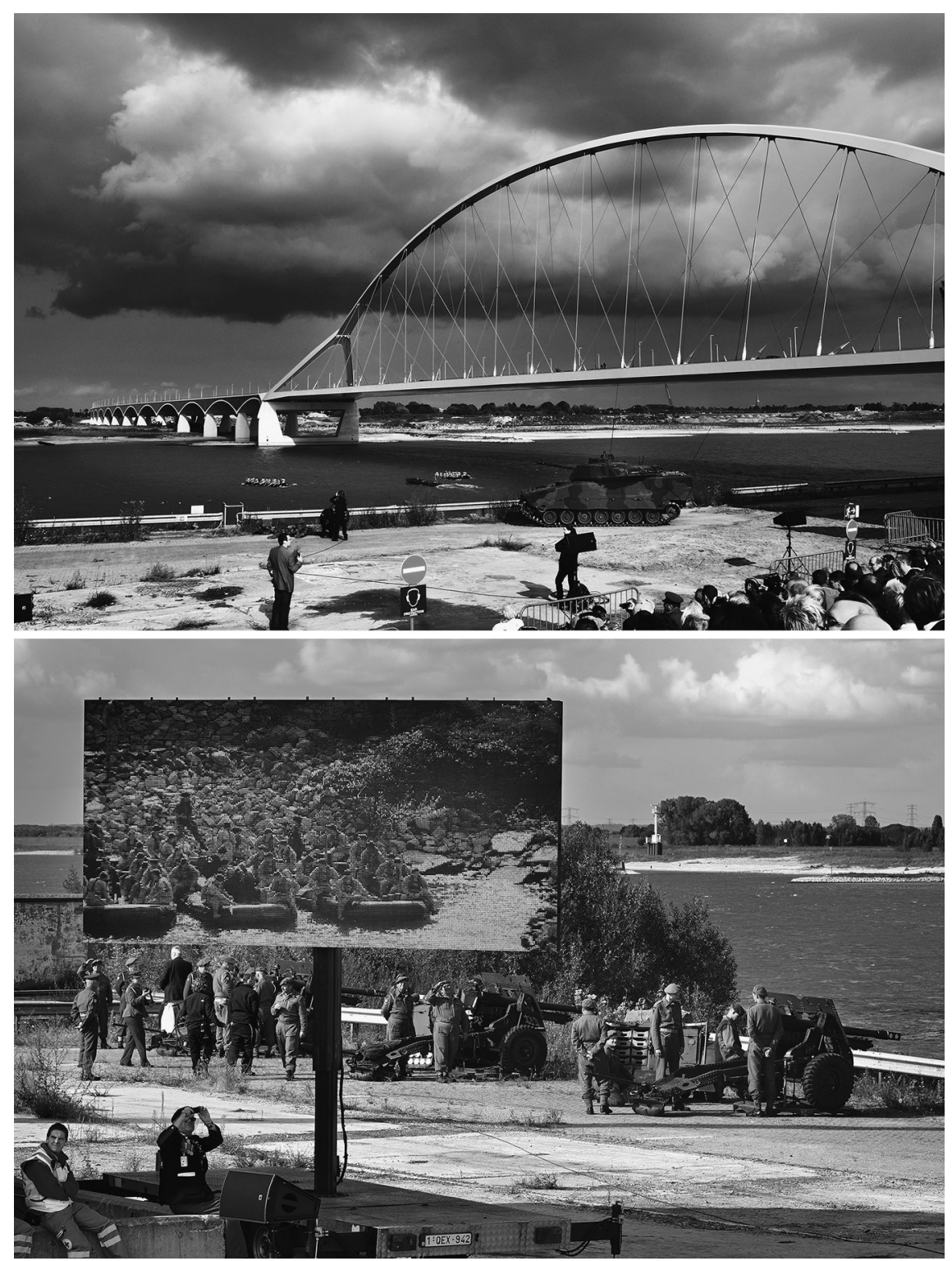

FIGURES 1 AND 2 WW2 Veterans and Royal Artillery reenactors at Nijmegen Bridge, Sept. 2014. PHOTOS F. MEHRING.

The diversity and multiplicity of perspectives typical of World War II commemorative events makes the re-appropriation of history in these events at least potentially a more conscious (and self-conscious) process. One of the indications of this (self-)consciousness is the fact that there seems to be a 
dissociation between on-site or near-site commemoration, and the kind of military reenactment that thrives on a replicated object-level and attempts at enacted proximity. ${ }^{4}$ Another one is the use of music in Operation Market Garden events on YouTube videos. As I will try to show using a variety of formats from the body of the video samples, the use of music opens further vistas on reenactments. There is a bandwidth from attempts at "authentic" identification, via the use of "filmic" motifs trying to achieve an affective association with the role model (Bullerjahn 2001, 200), to assurances of distance.

To my knowledge, no scholarly paper has attempted to include music in its assessment of reenactments, even though in a situation where the perception and reproduction of histories are governed by an affective turn, the presence and role of the music accompanying this turn might be important. The role of music in movies is part of the supportive system (Bullerjahn 2001, Burt 1994). It can be traced to 18 th and 19th century melodrama (Pisani 2014), therefore has been around long enough to establish "the need to coordinate music with the affective contents of the visuals, as opposed to simply providing some sort of 'cine-muzak' " (Brown 1994, 13). The use of music to accompany their actions by U.s. soldiers in Vietnam has become popular folklore, based on accounts by Michael Herr and others (Herr 1977, Fish 2002). Already Stephen Crane had noticed how according to conventional standards heroic deeds in particular seemed to generate accompanying sound. In his novel The Red Badge of Courage, young Henry Fleming has barely left the battlefield, when he is already parading his memories in front of his inner eye: "Those performances which had been witnessed by his fellows marched now in wide purple and gold, having various deflections. They went gayly with music. It was pleasure to watch these things" (Crane 1962, 108).

The presence of music at reenactments should therefore not come as a surprise, particularly when there is a larger audience and voiceover narration. Even less surprising is the presence of musical scores in reenactment videos, given their frequent aspiration to para-filmic quality. After all, among the purposes of music in (documentary) films are the evocation of a historical time, and the creation of a reception as communal and collective practice (Schneider 1989, 106, 110). About half of the videos sampled for this study

4 One of the few battle-reenactments of this kind on YouTube is "Battle for Arnhem-A Bridge Too Far Tribute" (Historical Aviation Film Unit, 2014), showing paratroopers jumping from a civilian DC 3, a replicated glider, and a firefight between British and German forces-in New Zealand in 2007, with voice-over commentary providing info on the actual battle, and commentary on the Levine film. The battle takes place on a treeless plain. There is no musical soundtrack. 
were accompanied by some sort of musical score. Typologically, they can be categorised into four groups

1. memorial / commemorative events, accompanied by

a) music played on the occasion or

b) with added soundtrack

2. parades / pageantric events, accompanied by

a) music provided by organizers

b) voiceover (if included) \& soundtrack by editor

3. (battle) reenactments (with or without soundtrack)

4. "movies" (with soundtrack \& texts)

Given the proximity of reenactments to war movies, the videos and their music might be expected to conform to war movie conventions. Also, both movies covering Operation Market Garden provide memorable musical motifs, notably so the suite composed for A Bridge Too Far by John Addison, who was a veteran of the British Xxx Corps (Addison 1976, cf. Thomas 1991, 132-145). However, the range of music used by the makers of the YouTube videos sometimes extends beyond the obvious choices, and sometimes chooses the overly obvious (cf. Burt 1994, 80). In order to grasp their range of possibilities-given that none of the musical scores were expressly composed for the videos they accompany-it is useful to return to a triadic distinction originally introduced by Hansjörg Pauli (Pauli 1976, 104), who claimed that film music served three basic functions: to paraphrase (supportive of the message, integrated), to polarise (when the music gives direction to an otherwise uncertain meaning), and thirdly Kontrapunktierung, which for the sake of simplification I will adapt and translate here as subversion. The model has shortcomings (Schneider qtd. in Bullerjahn 2001, 39; and Bullerjahn 2001, 38), and Pauli himself modified it, but it is useful here in the original form in so far as these three functions are usually visible as results of the rather openly displayed authorial intentionality so typical of YouTube videos.

\section{Example 1: "Slow March massed pipes and drums John Frost Bridge Arnhem" (pieterwzn 2009)}

Type: 1a. The pipes and drums of the Southern Highlanders perform John Cameron's 1856 lament "The Mist Covered Mountains" on the occasion of the 65 th remembrance.

While the units deployed at Arnhem were not particularly Scottish, bagpipe music had already been used to underscore the parachuting operation in Theirs is the Glory (Hurst 1946) and during the final pull-out, a 
piper can not only be heard but also faintly seen (1:17). Also, a bagpipe lament somehow seems an ideal response to heroic failures.

\section{Example 2: "Race to the bridge 2012 Renkum-Arnhem" (pkokkie3, 2012)}

Type: $2 \mathrm{a}$ or b. The annual "Race to the Bridge" parade of military vehicles is supposed to be a reenactment of the British paratroopers' advance from Renkum Heath, where many of them had landed, into the city of Arnhem to capture the bridges. Most of the vehicles seen are variants of the standard Willys "Jeep," some of which were historically deployed by British glider planes, as well as motorcycles and bicycles. The presence of the bicycles and (at 4:0o and 5:26) several German Kübelwagen and what looks like a 1940s German $L L G$ fire engine repainted to resemble a military truck, can be explained by their having been commandeered; the appearance of U.s. trucks and a DUKW goes beyond authenticity because of the character of the event as a mixture of reenactment and parade. Ironically, the seven welbikes in the parade have every historical reason to be there, while they were left out of both movies-possibly because the minuscule one-seater, especially developed for airborne troops, looks simply ridiculous in practice. The music, performed by н м Royal Marines Band, has a similar tendency towards the involuntarily comical, in so far as the first march heard (probably from loudspeakers near the position of the camera-person, or else cut into the film in addition to the sounds of vehicles and visitors audible throughout), is American John Philip Sousa's "The Liberty Bell" (1893). As a choice for a (failed) liberation, this might be considered appropriate, but this march was also the theme from the Monty Python's Flying Circus in the 196os. The (unintentional) comicality is underscored by the position of the camera, as the subtitle announces, "in front of Snackbar Lunchroom Airborne."

\section{Example 3: "Arnhem Bridge: Operation Market Garden. Reenactment 2010" (bazaoo78)}

Type: 2a. Other than what the title indicates, this short video does not show Arnhem Bridge, nor does anything in the movie indicate a relation to Operation Market Garden. A group of British paratrooper reenactors with a jeep-possibly participants in the 2010 "Race to the Bridge"-appropriate the music played over a loudspeaker system for an impromptu dance. That this is not a "hardcore" (or "campaigner") group is easily visible from the fact that their majority seem to be at least in their fifties, including the one dancer, and that the other dancer is a young woman, whose modern hairdo 
is visible under her red beret. They are dancing a boogie to the Andrews Sisters' version of 'Don't Sit Under the Apple Tree (with Anyone Else but Me)" written by Sam H. Stept, with lyrics by Lew Brown and Charles Tobias.

The choice of music at this point appears to have been coincidental, the action spontaneous and, considering that the woman is supposed to portray a paratrooper, even "out of character" from the point of view of authenticity. At the same time, their spontaneous appropriation of the tune echoes numerous scenes from the days of liberation. It might even be an (unintentional) commentary on a diary entry for October $17^{\text {th }}, 1944$ by a young man from Nijmegen, Jan Hendriks, who had taken to playing for the liberators in bars: "'s Avonds ging ik weer piano spelen voor de Tommy's [sic]. Het was er gezellig. Ze waren verbaasd dat ik zoveel swingnummers kan spelen, zoals 'Lady be good', 'In the mood' en dergelijke" (Afdeling Educatie Nationaal Bevrijdingmuseum 1944-1945, n.y., 24). ${ }^{5}$ Hendriks' diary in turn stands in contrast to a post-war song claiming "Ik kan niet swingen" (Mehring 2014) about Dutch girls and Canadian and British liberators-obviously, some Nijmegenaren could.

\section{Example 4: Battle Of Arnhem 17 September 2011 (Ederveen 2011)}

Type: $2 \mathrm{~b} / 3$. The short film concentrates on airplanes flying over, and on a line of vehicles moving along a dirt road in the Ginkelse Heide area used annually for the reenactment of the drive up 'hell's highway' and the airborne drop. There was a musical score provided by the organisers, as loudspeaker masts are clearly visible. At ca. 4:10, a text panel informs the audience that the presentation will now go to tinted format to give the video a more authentic feeling: "We gaan de beelden even weer aanpassen om het geheel een authentiek tintje te geven."

The music also changes-to the British national anthem! This does tie in with the gratefulness resonating in the video commentary, but more importantly, it shows an interesting perception of the "authentiek" as decidedly filmic; or, more precisely, of reality as newsreel. The original events had of course been as colourful, or colourless, as the reenactment was - the same time of the year, the same colour uniforms, vehicles etc. The appropriation of history here is one that attempts to be toeing the line of hegemonial opinion, to the point where that attempt becomes comical in its wellintentioned choice of form and soundtrack (cf. Burt 1994, 8o).

5 "In the evening I went again to play the piano for the Tommies. It was rather chummy. They were surprised that I could play so many swing pieces such as 'Lady Be Good, 'In the Mood', and the like." 


\section{Example 5: "Veterans Flight—Parachute Group Holland—Market Garden-Wolfheze, 21. Sept. 2012" (Redmanta84, 2012)}

Type 3. Reenactment slide show with text panels and music. The Parachute Group Holland is a club specialising on jumps with the old military type of round canopy parachutes. They regularly participate in the commemorative Market Garden reenactment jumps. In 2012, two British "1st Airborne Arnhem veterans Harold Padfield, Tom Carpenter, and Dutch para veteran Theo Jacobs," as the explanatory note on the webpage states (Redmanta 842014 ) were with them on the plane (a restored Douglas C- 47$).{ }^{6}$

The music is the main theme from the ego-shooter game Medal of Honor, (1999) composed by Michael Giacchino and chosen probably because of its proximity to Addison and other war movie soundtracks as well as for its title. This is what Norbert Jürgen Schneider refers to as "mood music" to inspire (Schneider 1989, 106). The (Congressional) Medal of Honor is the highest decoration awarded to U.s. soldiers - a fact that creates a certain irony in so far as none of the participant veterans in this reenactment were Americans. The music serves to enhance the reenactment character of the event in so far as the ego-shooter game contains all the fighting that is invisible from the slides, or visible only in so far as it is inscribed on the veterans in their red-bereted veterans' suits with their rows of medal ribbons, and in the partly modern, partly historic (and mixed, American and British) paratrooper uniforms.

\section{Example 6: "Market Garden-Driel, 18th September 2010" (MarsAssessor 2010)}

Type 3. Reenactment of the jump of Major General Stanisław Sosabowski's 1st (Polish) Independent Parachute Brigade, which suffered high losses during the operation. Only the mention of Driel indicates to audiences that this has anything to do with the Polish Brigade. The reenactors jumping from a historical C- 47 Dakota were members of Pathfinder Europe, the oldest parachute group organisation

6 The text does not go into detail about the role or function on Mr. Jacobs, who does, however, appear on a website of a reunion of Dutch commando soldiers in 2015. World War II participation is not mentioned rather than "politionele acties in Indië," that is, the colonial conflict in what became Indonesia in 1949 (Korps Commandotroepen 2015) - a particular irony in so far as this would imply that two veterans who fought for the liberation of the Netherlands from Nazi rule shared the plane with a Dutchman who fought against liberation from colonial rule. 
using round canopy parachutes. The Polish text and song, sounding like from a historical radio transmission or record, remain unidentified in the descriptive notes accompanying the video. The spoken text identifies the Arnhem operation, and mentions Sosabowski's men. "Marsz Spadochronowy" is the Polish paratroopers' march. ${ }^{7}$ Fittingly enough-but, ironically, it mentions Wilna (Vilnius) and Lwów (Lviv) as areas of liberating operations, neither of which are now Polish territory, and fails to mention Arnhem. No other indication is given in the film that the parachutists in the video are supposed to be Sosabowski's men - the identification runs solely via the musical score and the explanatory text. This creates, in Pauli's terms, polarisation - the music generates a meaning that the images alone cannot convey. Both Cornelius Ryan's minutely researched book (Ryan 1974) and the Hollywood film A Bridge Too Far have described the Poles as marginalised, and ironically the use of Polish in the soundtrack of this video continues in this direction rather than bringing them closer. It is a small event, performed by what looks like no more than twenty men (three planes, or three times the same plane, with six parachutists on each run), with the Polish song "othering" the otherwise unrecognisable Poles.

\section{Example 7: “Terug naar September 1944” (Sanders 2008)}

Type 4 Movie (8:22). This example proves best that Jenny Thompson's above-quoted statement about acting in a war-movie while watching it contains more than a kernel of truth. The aspiration to produce a "real" movie is visible throughout, starting with the assertion on the webpage that there is a production company. ${ }^{8}$ The production was filmed at the 2008 Open Monumenten Dag in Fort Vechten, where a group called Vereniging Historische Militaria and others named in the credits reenacted a Market Garden scenario. The story, told in four scenes, goes beyond "September 1944 " to encompass the liberation in May 45 as well. The first scene, showing the German occupation, uses the same Medal of Honor soundtrack used by Ex. 5 until it is superseded by air-raid sirens and sound of airplanes. Advancing British paras are fired on by the Germans. The following battle scene switches to black and white at 4:45 with a German voiceover about

7 Thanks to my friends Monika Krol and Marek Gryglewicz for help with this text.

8 Sanders has produced a number Roman period reenactment videos, and at least one more ww2, about the "Battle for Dordrecht -1940-" (https://www.youtube.com/watch?v=VJOLDhoOg6o, acc. Sept. 5, 2015). 
the defeat of the British airborne forces at Arnhem - this passage is obviously meant to look and sound like a German Wochenschau, and, like Ex. 4, to become more "real" that way. However, it is not directly modelled on, or using the text of, the real Wochenschau No. 734 which reported the Arnhem fight (Worldly Life Distracts You, 2015). The third scene opens with a text panel announcing " 5 May 1945" but the following scenario showing the liberation of the Netherlands by British and Canadian infantry is closest to the Eindhoven passage in A Bridge Too Far, with celebrating Dutch civilians singing "Oranje Boven," an impression strongly reinforced by the use of music from Addison's suite for the opening of the scene. Somewhat incongruously, the film then (6:45) switches back to a hospital scene, modelled on passages from A Bridge Too Far yet without music, before the credits start rolling.

\section{Conclusion}

The theatricality of reenactments has been established beyond doubt, their open-air character, lack of script, and their structural simplicity notwithstanding. Their predominantly assertive stance towards hegemonial historiography, their lack of accessible scripts, and their derivative and epigonal character have not rendered them particularly attractive for scholars. In fact, they might have shielded them so far from deeper and more systematic analysis. However, a number of aspects that link reenactments to other, more "artistic" forms of performance, can be established. Their proximity to film was already stated by Jenny Thompson. In conclusion to this paper, I would like to advance several claims that go beyond Thompson, Agnew, and my own research so far.

1. Modern and postmodern reenactments already presuppose and include a conceptually filmic performativity running throughout. Battle reenactments have always been war movies without cameras. With the ubiquitousness of simple hand-held, camera devices, however, that has changed towards even closer approximation. Reenactors can now participate in their own war movie, and not only watch themselves while doing it, but they can re-watch and upload it on YouTube afterwards.

2. Commemorations of 2oth-century events integrate veterans, descendants of veterans, contemporary units that continue the tradition of the original ones, and reenactor groups / living history presentations, in a 
novel combination that leaves the seams of historiography more visible than in the more unified attempts at "authentic" reenactments.

3. Reenactment videos on YouTube are not just bad amateur war movies. Not being able to narrate a full story, and develop characters, they resemble more the original actualities film history started with-short clips up to the size of one-reelers which represent something the audience is already familiar with, so the clip / movie can work with inferences, show only excerpts and fragments, and rely on audiences to fill in the rest.

4. Musical scores are one form by which authors / editors attempt to overcome the obvious limits of YouTube video clipping of reenactments and commemorative events, but very few YouTube video producers are able to compose their own soundtrack. In most cases where there is an accompanying soundtrack, at least in the samples investigated here the makers used prefabricated material, and tried to stay on the hegemonially beaten track.

5. As at least two of the examples in this study show, however, music in reenactment videos can also be used to extend the range of the genre. The "paras" dancing to "Don't Sit Under the Apple Tree" both reassert the genre - this was a war-time song, and couples danced to it—and they subvert it. Their age and gender indicate that their view of what might pass as authentic is considerably broader than what would be covered by any idea of vraisemblance. And finally, Coldplay's "Can anybody fly this thing...?" just when the B 25 Mitchell heaves in view is subtle irony, and shows subversive potential, as do a number of other videos that focus primarily on the airplanes, or the jumps.

6. The amalgamation of older forms of commemoration with presentday formations of living history presentation has changed the traditional militaristic gravity of commemorative events into a lighter, and in the Bakhtinian sense more carnivalesque and polyvocal format. This is underscored by the various ways in which music is used.

7. The "commemorative reenactment" as an amalgam form constitutes another sub-category in the typology of Living History / 'Geschichtstheater' which to my knowledge has not previously been identified, or analysed. As an active, participatory format commemorating in this particular case the liberation of the Netherlands, and of Western Europe, its integral playfulness and potential subversiveness seem more appropriate for the 21st century than any continuation of older hegemonial forms of commemoration could possibly be any longer. 


\section{Bibliography}

Addison, John. 1977. “[A Bridge Too Far Suite].” Mgm Motion Picture Soundtrack. https://www.youtube.com/watch?v=2n7vrvMoiO4 (acc. August 14, 2014).

Afdeling Educatie Nationaal Bevrijdingmuseum 1944-1945 (n.y.). Nijmegen 44. Forever Free. Lesbrief Bovenbouw Basisonderwijs. Groesbeek: Nationaal Bevrijdingmuseum 1944-1945.

Agnew, Vanessa ed. 2004. Criticism 46.3 [special issue on reenactment].

Agnew, Vanessa. 2007. "History's Affective Turn: Historical Reenactment and Its Work in the Present." Rethinking History 1 1.3, 299-312.

Assmann, Aleida. 2006. “Memory, Individual and Collective.” Robert E. Goodin, Charles Tilly, eds., The Oxford Handbook of Contextual Political Analysis. Oxford: Oxford University Press.

Assmann, Jan. 1995. "Collective Memory and Cultural Identity." New German Critique $65125^{-133 .}$

Assmann, Jan. 2008. "Communicative and Cultural Memory." Astrid Erll, Ansgar Nünning, eds., Cultural Memory Studies. An International and Interdisciplinary Handbook. Berlin/New York: de Gruyter, 109-118.

Baudrillard, Jean. 1983. Simulations. New York: Semiotext(e).

bazaoo78. 2010. "Arnhem Bridge: Operation Market Garden. Reenactment 2010." https://www.youtube.com/watch?v=b1etyT5vkF8\&feature=youtube_gdata_player (acc. July 14, 2014).

Berens, Daniel J. 2008. "WWII Reenactment in West-Central Wisconsin: Context of History and Memory from the Last World War." [B.A. Thesis] History 489 Research Seminar, UWI Eau Claire. http://minds.wisconsin.edu/bitstream/handle/1793-/ 2879o/BerensSpringo8.pdf? sequence $=2$.

Brown, Royal S. 1994. Overtones-Undertones. Reading Film Music. Berkeley: UC Press.

Bullerjahn, Claudia. 2001. Grundlagen der Wirkung von Filmmusik. Augsburg: Wißner Verlag.

Burt, George. 1994. The Art of Film Music. Boston: Northeastern University Press.

Coldplay. 2000. "High Speed." Parachutes.

Connerton, Paul. 1989.Bodily Practices.How Societies Remember.Cambridge:Cambridge University Press

Crane, Stephen. 1962 [1895]. The Red Badge of Courage, eds. Sculley Bradley, Richmond C. Beatty, E. Hudson Long, New York: Norton, 1962. [orig. D. Appleton \& Co., 1895]. Ederveen, Jan. 2011. "Battle Of Arnhem 17 September 2011." https://www.youtube .com/watch?v=tZnoa1ig8kQ (acc. 27.06. 2014).

EDtv.nl [Eindhoven Dagblad]. 20o9. "Herdenking Market Garden-Parachutisten dropping." http://www.youtube.com/watch?v=UST 8qrnBYRQ (acc. June 26, 2014). 
Fischer-Lichte, Erika. 2012. "Die Wiederholung als Ereignis. Reenactment als Aneignung von Geschichte." Ulf Otto, Jens Roselt, eds. Theater als Zeitmaschine. Zur performativen Praxis des Reenactments. Theater- und kulturwissenschaftiche Perspektiven. Bochum: transcript, $13^{-} 5^{2}$.

Fish, Lydia. 2002. "Songs of Americans in the Vietnam War." http://faculty.buffalostate .edu/fishlm/folksongs/americansongs.htm (acc. July 12, 2015)

Hemmen, Paul. 20o9. "Market Garden Memorial Jump at Ginkelse Heide." https:// www.youtube.com/watch?v=k9suQcByh4U (acc. August 14, 2014).

Herr, Michael. 1977. Dispatches. New York: Alfred A. Knopf.

Historical Aviation Film Unit. 2014. "Battle for Arnhem-A Bridge Too Far Tribute." http://www.youtube.com/watch?v=LwIho_oCrI.

Hochbruck, Wolfgang. 2008. "Relikte, Reliquien und Replikate: Der Umgang mit historischen Objekten im Geschichtstheater." Historische Anthropologie 1, 138-153.

Hochbruck, Wolfgang. 2012. "Reenactment: Freilufttheater und Gedenkort." Ulf Otto, Jens Roselt, eds. Theater als Zeitmaschine. Zur performativen Praxis des Reenactments. Theater- und kulturwissenschaftliche Perspektiven. Bochum: transcript, 189-211.

Hochbruck, Wolfgang. 2013. Geschichtstheater: Formen der "Living History." Eine Typologie. Bielefeld: transcript.

Hochbruck, Wolfgang. 2016. "Reenacting Across Six Generations, 1863-1963." Sarah Willner, Georg Koch, Stefanie Samida, eds. Doing History. Performative Praktiken in der Geschichtskultur. Münster: Waxmann, 91-110

Hurst, Brian Desmond, dir. 1946. Theirs is the Glory. Gaumont.

Jameson, Frederic. 1988. "Postmodernism and Consumer Society." E. Ann Kaplan, ed., Postmodernism and Its Discontents: Theories, Practices. London: Verso.

Korps Commandotroepen. 2015. "Reünie Commandovereniging RST." http://www .korpscommandotroepen.nl/stichting-nieuws/reunie-commandovereniging-rst/ (acc. September 5, 2015).

Langenohl, Andreas. 2008. "Memory in Post-Authoritarian Societies.” Astrid Erll, Ansgar Nünning, eds., Cultural Memory Studies. An International and Interdisciplinary Handbook. Berlin/New York: de Gruyter, 163-172.

Levine, Joseph E., prod. 1977 A Bridge Too Far. Richard Attenborough, dir. MGM

MarsAssessor. 2010. "Market Garden-Driel, 18th September 2010." https://www .youtube.com/watch?v=2aymoPwCoxA.

McCabe, Doug. 2014. "The Cornelius Ryan Collection: Media, Memory, and Archiving Operation Market Garden" Music \& Movies-National and Transnational Approaches 2oth SERCIA Conference, Nijmegen, Radboud University, Sept. 18.-20.

McCalman, Iain, Paul A. Pickering, eds. 2010. Historical Reenactment. From Realism to the Affective Turn. London: palgrave macmillan. 
Mehring, Frank. 2014. "The Soundtrack of Liberation." Music \& Movies - National and Transnational Approaches 2oth SERCIA Conference, Nijmegen, Radboud University, Sept. 18-20.

Nieuws uit Nijmegen. 2014. "Waalcrossing Market Garden 1944 Eerbetoon 2014." https://www.youtube.com/watch?v=SZNpd7gmluw (acc. September 5, 2014).

Pauli, Hansjörg. 1976. "Filmmusik: Ein historisch-kritischer Abriß." Hans-Christian Schmidt, ed. Musik in den Massenmedien Rundfunk und Fernsehen: Perspektiven und Materialien. Mainz: Schott, 91-119.

Pieterwzn. 2009. "Slow March massed pipes and drums John Frost Bridge Arnhem" https://www.youtube.com/watch?v=0HWIKYNSEPE (acc. July 12, 2014)

Pisani, Michael V. 2014. Music for the Melodramatic Theatre in Nineteenth Century London \& New York. Iowa City: University of Iowa Press.

pkokkie3. 2012. "Race to the bridge 2012 Renkum-Arnhem" https://www.youtube .com/watch?v=b763RUwWHIY (acc. July 12, 2014).

Redmanta84. 2012. "Veterans Flight-Parachute Group Holland-Market GardenWolfheze, 21. Sept. 2012." http://www.youtube.com/watch?v=FNebFFm7VY4 (acc. June 26, 2014).

Ryan, Cornelius. 1974. A Bridge Too Far. New York: Simon \& Schuster

Sanders, Mark. 2008. "Terug naar September 1944." Script: Marcel van Spronsen. Phalera Productions. http://www.youtube.com/watch?v=9bvm_mpdNUs (acc. September 5 , 2014).

Schlehe, Judith, Michiko Uike-Bormann, Carolyn Oesterle, Wolfgang Hochbruck, eds. 2010. Staging the Past. Themed Environments in Transcultural Perspectives. Bielefeld: transcript.

Schlote, Christiane, Eckart Voigts-Virchow. 2008. "Introduction: "The Creative Treatment of Actuality'-New Documentarism." ZAA 56.2, 107-116.

Schneider, Norbert Jürgen. 1989. Handbuch Filmmusik II. Musik im dokumentarischen Film. München: Ölschläger.

Schneider, Rebecca. 2011. Performing Remains. Art and War in Times of Theatrical Reenactment. London: Routledge.

Thomas, Tony. 1991. Film Score: The Art and Craft of Movie Music. Burbank CA: Riverwood [John Addison chapter, 132-145].

Thompson, Jenny. 2004. Wargames. Inside the World of 2oth Century War Reenactors. Washington: Smithsonian.

Worldly Life Distracts You. 2015. "Wochenschau Arnheim September 1944" (i.e. Deutsche Wochenschau Nr. 734) [Australian War Memorial Fo 1964]. https:// www.youtube.com/watch?v=nw6fkc4kBoE (acc. September 1, 2015). 


\section{On the Road to Nijmegen-Earle Birney and Alex Colville, 1944-1945}

Hans Bak

\section{Introduction $^{1}$}

That the Canadian army played a significant role in liberating the Netherlands from German occupation between D-Day (June 6, 1944) and the unconditional surrender of Germany on May 5, 1945 has been welldocumented by historians, diarists, and even-if to a lesser extent than the contributions made by the British and American forces-by novelists and poets (Bosscher; Davey; Zuehlke). The carefully maintained Canadian Military Cemeteries in the Netherlands - at Bergen op Zoom (968 graves), Groesbeek (2,400 graves) and Holten (close to 1,400 graves)—form a compelling memorial to the sacrifice of many Canadian lives. The Canadian war effort was decisive on at least three major fronts. In November 1944, in the Southwest, Canadians fought the Germans at the battle of Walcheren, to keep control over the Scheldt estuary and thus ensure open access to the Antwerp harbor for the Allied forces. In September 1944, in the Southeast, the Allied forces, predominantly American, marched through a narrow corridor from Belgium into the Eindhoven area and on to Nijmegen, as part of Operation Market Garden-its aim being to secure the two strategic bridges, one at Nijmegen across the river Waal, the other at Arnhem, across the Rhine. The city of Nijmegen was technically liberated by the Allied forces on September 20, but with Operation Market Garden grinding to a halt just north of Nijmegen - the bridge at Arnhem proving, in Cornelius Ryan's famous words "a bridge too far" — the city remained under German fire and shelling through the winter and spring of 1944-1945. In November,

1 I thank the following people for helping me to locate poetic and visual representations of Nijmegen by Canadian poets and painters: Sherrill Grace, University Killam Professor, Department of English, University of British Columbia; Laura Brandon, Historian, Art and War, Canadian War Museum, Ottawa; Amber Lloydlangston, Historian, Art and War, Canadian War Museum, Ottawa; Jane Naisbitt, Head, Military History Research Centre and Collections Information, Canadian War Museum, Ottawa.

(C) HANS BAK, 2018 | DOI 10.1163/9789004292017_008

This is an open access chapter distributed under the terms of the prevailing CC-BY-NC License at the time of publication. 